\title{
Fasilitas, Harga, Kualitas Pendidikan, Dan Lokasi Sebagai Determinan Keputusan Siswa Memilih Jasa Pendidikan Di SMK Muhammadiyah Imogiri (Studi Kasus Pada Jurusan Tata Busana)
}

\author{
Ari Dwi Astuti \\ Mahasiswa Magister Manajemen Universitas Ahmad Dahlan \\ Email: arieda.astuti@gmail.com
}

\begin{abstract}
Abstrak
Pada pendidikan kejuruan memberikan suatu bentuk pengembangan bakat, pendidikan dasar keterampilan dan kebiasaan-kebiasaan yang mengarah pada dunia kerja yang dipandang sebagai latihan keterampilan. Banyaknya lembaga pendidikan Sekolah Menengah Kejuruan (SMK) mengakibatkan persaingan yang sangat ketat antar SMK. Beberapa faktor pemasaran dapat dijadikan strategi yang cocok untuk membuat para calon siswa mengetahui beberapa keunggulan yang sekolah tawarkan seperti misalnya: fasilitas yang ada di sekolah, memberikan harga yang kompetitif, memberikan kualitas pendidikan yang memadai dan lokasi yang aman dan terjangkau oleh para siswa. Penelitian ini bertujuan untuk (1) menganalisis pengaruh fasilitas terhadap keputusan siswa memilih jasa pendidikan SMK Muhammadiyah Imogiri jurusan Tata Busana, (2) menganalisis pengaruh harga terhadap keputusan siswa memilih jasa pendidikan SMK Muhammadiyah Imogiri jurusan Tata Busana, (3) menganalisis pengaruh kualitas pendidikan terhadap keputusan siswa memilih jasa pendidikan SMK Muhammadiyah Imogiri jurusan Tata Busana, (4) menganalisis pengaruh persepsi lokasi terhadap keputusan siswa memilih jasa pendidikan SMK Muhammadiyah Imogiri jurusan Tata Busana.Teknik sampling yang digunakan adalah teknik probability sampling dengan metode simple random sampling, yang terdapat empat variabel bebas $(\mathrm{X})$ dan satu variabel terikat $(\mathrm{Y})$. Hasil penelitan ini menunjukkan bahwa (1) Tidak ada pengaruh positif fasilitas terhadap keputusan siswa memilih jasa pendidikan SMK Muhammadiyah Imogiri. (2) Ada pengaruh positif harga terhadap keputusan siswa memilih jasa pendidikan SMK Muhammadiyah Imogiri. (3)Ada pengaruh positif kualitas pendidikan terhadap keputusan siswa memilih jasa pendidikan SMK Muhammadiyah Imogiri. (4) Ada pengaruh positif lokasi terhadap keputusan siswa memilih jasa pendidikan SMK Muhammadiyah Imogiri.
\end{abstract}

Kata kunci :Keputusan memilih jasa pendidikan, fasilitas, harga, kualitas pendidikan, lokasi

Abstract

Vocational education provides a form of talent development, basic education skills and habits that lead to the world of work which is seen as skills training. The large number of vocational high school (SMK) educational institutions has resulted in very tight competition between SMK. Several marketing factors can be used as a suitable strategy to make prospective students aware of some of the advantages that schools offer, such as: existing facilities in schools, providing competitive prices, providing adequate quality education and a safe and affordable location for students. aimed to (1) analyze the effect of facilities on student decisions to choose educational services at SMK Muhammadiyah Imogiri majoring in Fashion,. This research used random sampling, which contains four independent variables $(X)$ and one dependent variable $(Y)$. The results of this study indicate that (1) There is no positive effect of facilities on student decisions to choose educational services at Muhammadiyah Imogiri Vocational School. (2) There is a positive effect of price on the decision of students to choose the educational services of Muhammadiyah Imogiri Vocational School. (3) There is a positive influence on the quality of education on students' decisions to choose the educational services of SMK Muhammadiyah Imogiri. (4) There is a positive effect of location on students' decisions to choose the educational services of Muhammadiyah Imogiri Vocational School.

Keywords: The decision to choose educational services, facilities, price, quality of education, location 


\section{PENDAHULUAN}

Pada pendidikan kejuruan memberikan suatu bentuk pengembangan bakat, pendidikan dasar keterampilan dan kebiasaankebiasaan yang mengarah pada dunia kerja yang dipandang sebagai latihan keterampilan. Siswa akan disiapkan untuk memasuki persaingan di dunia kerja. Kegiatan pembelajaranpun tidak hanya terjadi di sekolah, namun kegiatan praktik industri di dunia kerja nyata sangat ditekankan untuk mendapatkan dan meningkatkan pengalaman bekerja di persaingan dunia kerja

SMK Muhammadiyah Imogiri merupakan salah satu dari banyaknya sekolah menengah kejuruan di Kecamatan Imogiri diantaranya SMK Merah Putih dan SMK Taman Siswa. Menentukan pilihan yang tepat akan dipertimbangkan oleh para calon siswa antara sekolah menengah kejuruan mana yang layak dipilih serta mengetahui keunggulan apa saja yang sekolah tersebut miliki. Maka para calon siswa bisa lebih bijak lagi dalam memilih sekolah menengah kejuruan tawarkan.

Pada umumnya para calon siswa akan tertarik pada sekolah yang memiliki keunggulan yang sesuai dengan apa yang siswa butuhkan. Hal itu dapat diartikan bahwa setiap sekolah harus memiliki keunggulan-keunggulan yang dapat memungkinkan untuk menarik para calon siswa agar memutuskan memilih masuk ke sekolah tersebut.

Beberapa faktor pemasaran dapat dijadikan strategi yang cocok untuk membuat para calon siswa mengetahui beberapa keunggulan yang sekolah tawarkan seperti misalnya, sekolah tersebut memiliki bukti fisik (physical evidence) yaitu suatu lingkungan dimana sekolah dan siswa dapat berinteraksi, dan didalamnya terdapat komponenkomponen tangible (berwujud) yang bekerja mendukung kinerja atau komunikasi dari jasa pendidikan tersebut. Dalam proses penyampaian jasa pendidikan kepada siswa, harus memperhatikan gaya bangunannya (yaitu kesesuaian antara segi estetika dan fungsionalnya sebagai lembaga pendidikan) serta fasilitas penunjangnya (seperti kelengkapan sarana pendidikan, peribadahan, olahraga, dan keagamaan).

Indikasi paling pertama dan yang utama adalah masalah biaya/harga pendidikan. Biaya pendidikan merupakan salah satu elemen penting untuk melancarkan penyelenggaraan pendidikan, hal ini guna memfasilitasi berjalannya kebijakan program sekolah. Pada umumnya para calon siswa akan memilih sekolah swasta dengan biaya yang kecil/rendah daripada sekolah yang lainnya.

Para calon siswa selain memperhatikan biaya/harga biasanya mereka juga akan melihat kualitas pendidikan yang dimiliki oleh sekolah yang akan dipilih, dengan melihat berapa banyak prestasi yang diperoleh/dimiliki sekolah tersebut, sekolah yang memiliki kegiatan ekstrakurikuler sebagai ajang pengembangan diri siswa saat di sekolah juga menjadi perhatian para calon siswa, dengan demikian para calon siswa bisa memilih ektra kurikuler berdasarkan bakat dan minat yang dimilikinya.

Diduga bahwa para calon siswa juga akan memilih sekolah dengan memperhatikan keunggulan dalam bentuk keterjangkauan tempat/lokasi sekolah. Pada umumnya para calon siswa akan memilih sekolah yang mudah dijangkau dan para calon siswa akan mempertimbangkan lingkungan dimana tempat sekolah itu berada (dekat dengan jalan utama/perumahan, kondisi lahan parkir, lingkungan belajar yang kondusif) dan transportasi (seperti kemudahan sarana transportasi menuju sekolah tersebut). Namun selain lokasi/tempat sekolah secara fisik (gedung/bangunan), tempat sekolah juga dapat dijangkau secara virtual yaitu melalui internet. Tersedianya situs suatu sekolah menjadi daya tarik, sehingga dari sana dapat diperoleh banyak informasi yang diperlukan tanpa harus datang ke lokasi sekolah tersebut.

SMK Muhammadiyah Imogiri merupakan Sekolah Menengah Kejuruan swasta yang cukup baik jika dilihat dari jumlah siswanya. Sekolah SMK ini selain mendidik muridnya dengan menggunakan teknologi yang modern, juga memberikan keunggulan seperti pendidikan agama Islam. Dengan sekolah di SMK Muhammadiyah Imogiri, diharapkan bisa meningkatkan kemampuan generasi penerus bangsa yang pandai dan memiliki akhlak yang mulia. Akan tetapi ada beberapa permasalahan yang dirasakan, karena sekolah SMK ini sedang berkembang, di mana jumlah muridnya mengalami fluktuasi sejak tahun 2012 yang cenderung terus menurun terutama untuk jurusan Tata Busana. 
Seiring dengan persaingan dalam pendidikan menengah atas, tahun ajaran 20132014 sampai dengan tahun ajaran 2019-2020 SMK Muhammadiyah Imogiri mengalami fluktuasi jumlah siswa baru untuk jurusan Tata Busana, yaitu mengalami peningkatan pada tahun 2013-2014 sampai dengan tahun 20152016 dan mengalami penurunan jumlah siswa baru yang terus menerus pada tahun ajaran 2016-2017 sampai dengan 2019-2020, sehingga dapat disimpulkan adanya penurunan yang cukup tajam. Guna meningkatkan jumlah siswa Tata Busana, hendaknya SMK Muhammadiyah imogiri berusaha untuk meningkatkan fasilitas yang ada di sekolah, memberikan harga yang kompetitif, memberikan kualitas pendidikan yang memadai dan lokasi yang aman dan terjangkau oleh para siswa.

Penelitian ini bertujuan untuk mengetahui pengaruh fasilitas, harga, kualitas pendidikan, dan lokasi terhadap keputusan siswa memilih jasa pendidikan SMK Muhammadiyah Imogiri jurusan Tata Busana.

\section{TINJAUAN PUSTAKA}

Kotler dan Keller (2016:277) mendefinisikan jasa sebagai berikut: "jasa adalah setiap tindakan atau unjuk kerja yang ditawarkan oleh salah satu pihak kepada pihak lain yang secara prinsip intangible (tidak berwujud) dan tidak menyebabkan perpindahan apapun". Sedangkan definisi jasa menurut Lupiyoadi (2013:5) adalah semua aktivitas ekonomi yang hasilnya tidak merupakan produk dalam bentuk fisik atau konstruksi, yang biasanya dikonsumsi pada saat yang sama dengan waktu yang dihasilkan dan memberikan nilai tambah (seperti misalnya kenyamanan, hiburan, keseharan atau pemecahan akan masalah yang dihadapi konsumen).

Definisi perilaku konsumen menurut Dharmmesta dan Handoko (2016:75) perilaku konsumen (consumer behavior) adalah kegiatankegiatan individu yang secara langsung terlibat dalam mendapatkan dan mempergunakan barang-barang dan jasa-jasa tersebut di dalamnya proses pengambilan keputusan pada persiapan dan penentuan kegiatan-kegiatan tersebut. Perilaku konsumen dalam melakukan pembelian sangat dipengaruhi oleh beberapa faktor. Terdapat 3 (tiga) faktor yang mempengaruhi perilaku konsumen dalam pembelian suatu produk. Faktor-faktor ini memberi pengaruh yang cukup signifikan terhadap konsumen dalam memilih produk. Menurut Kotler dan Keller (2016:179-184) faktor-faktor ini terdiri dari faktor budaya (cultural factor), faktor sosial (social factor), dan faktor pribadi (personal factor).

Keputusan konsumen dalam melakukan pembelian suatu produk merupakan suatu tindakan yang lazim dijalani setiap individu konsumen ketika mengambil keputusan pembelian suatu barang atau jasa. Keptusan membeli atau tidak membeli merupakan bagian dari unsur yang melekat pada diri individu konsumen yang disebut behavior, dimana merujuk pada tindakan fisik yang nyata. Menurut Alma (2018:97) mengemukakan bahwa keputusan pembelian adalah sebagai berikut : "Keputusan pembelian adalah suatu keputusan konsumen yang dipengaruhi oleh lingkungan seperti : kebudayaan (culture), kelas social (social class), keluarga (family), klub-klub (referensi group)". Sedangkan menurut Kotler dan Amstrong (2016:177) mendefinisikan keputusan pembelian sebagai berikut : Consumer behavior is the study of how individual, groups, and organizations select, buy, use and disposeof goods, service, ideas, or experiences to satisfy their needs and wants, yang artinya keputusan pembelian merupakan bagian dari perilaku konsumen yaitu studi tentang bagaimana individu, kelompok, dan organisasi memilih, membeli, menggunakan, dan bagaimana barang, jasa, ide atau pengalaman untuk memuaskan kebutuhan dan keinginan mereka.

Berdasarkan beberapa definisi tersebut peneliti memahami, bahwa keputusan membeli merupakan keputusan konsumen dalam memilih, membeli dan menggunakan barang atau jasa yang dipengaruhi oleh lingkungan seperti : kebudayaan (culture), kelas social (social class), keluarga (family), klub-klub (referensi group) untuk memuaskan kebutuhan dan keinginana mereka yang melalui beberapa proses keputusan pembelian yaitu : Problem Recognition (Pengakuan Masalah), Information Search (Pencari Informasi), Evalution of Alternatives (Evaluasi Alternatif), Purchase Decision (Keputusan Pembelian), Postpurchase Behavior (Perilaku Pasca Pembelian).

Fasilitas belajar merupakan sarana dan prasarana pembelajaran. Prasarana meliputi gedung sekolah, ruang belajar, lapangan olahraga, ruang ibadah, ruang kesenian dan peralatan olah raga. Sarana pembelajaran 
meliputi buku pelajaran, buku bacaan, alat dan fasilitas laboraturium sekolah dan berbagai media pembelajaran yang lain. Menurut Tjiptono (2015:152) mengatakan bahwa fasilitas adalah sumber daya fisik yang harus ada sebelum suatu jasa dapat ditawarkan kepada konsumen. Fasilitas adalah kondisi fisik dinamis yang berhubungan dengan produk, jasa, sumber daya manusia, proses, dan lingkungan yang memenuhi atau melebihi sedemikian rupa sehingga bentuk barang-barang yang berfungsi untuk menambah nilai suatu produk atau jasa lebih menarik.

Harga dalam konteks jasa pendidikan merupakan seluruh biaya yang dikeluarkan oleh siswa untuk mendapatkan jasa pendidikan yang ditawarkan oleh suatu jasa pendidikan. Penetapan harga ( SPP. Biaya pembangunan, biaya laboratoriun, biaya praktik jurusan) adalah elemen harga jasa pendidikan, pemberian beasiswa prosedur pembayaran dan syarat cicilan. Menurut Tjiptono (2016:218) menyebutkan bahwa harga merupakan satusatunya unsur bauran pemasaran yang mendatangkan pemasukan atau pendapatan bagi perusahaan. Sedangkan menurut Alma (2018:171) mengemukakan bahwa harga adalah nilai suatu barang yang dinyatakan dengan uang.

Kualitas atau mutu pendidikan mengacu pada proses pendidikan dan hasil pendidikan, atau prestasi yang dicapai oleh sekolah pada setiap kurun waktu tertentu. Prestasi yang dicapai atau hasil pendidikan (student achievement) dapat berupa hasil test kemampuan akademis, dapat pula prestasi dibidang lain seperti di suatu cabang olah raga, seni atau keterampilan tambahan tertentu. Bahkan prestasi sekolah dapat berupa kondisi yang tidak dapat dipegang (intangible) seperti suasana disiplin, keakraban, saling menghormati, kebersihan dan sebagainya. Menurut Kotler dan Keller (2016:164) kualitas produk adalah kemampuan suatu barang untuk memberikan hasil atau kinerja yang sesuai bahkan melebihi dari apa yang diinginkan pelanggan. Sedangkan menurut Kotler dan Amstrong (2014:11) kualitas produk adalah kemampuan sebuah produk dalam memperagakan fungsinya, hal ini terseluruhan durabilitas, reliabilitas, ketepatan, kemudahan pengoperasian dan reparasi produk, juga atribut produk lainnya.
Lokasi adalah merupakan faktor yang ikut berpengaruh pada kepuasan konsumen. Lokasi yang strategis menjadi nilai tambah bagi lembaga pendidikan untuk meningkatkan kepuasan konsumen dan berpengaruh pada pertumbuhan di masa depan. Lokasi dimana lembaga pendidikan memasarkan jasa kepada konsumen atau pelanggan sehingga siswa mudah menjangkau, mengakses dan memperoleh layanan produk dalam rangka memenuhi kebutuhannya. Menurut Tjiptono (2015:345) lokasi mengacu pada berbagai aktivitas pemasaran yang berusaha memperlancar dan mempermudah penyampaian atau penyaluran barang atau jasa dari produsen kepada konsumen. Sedangkan menurut Kotler dan Amstrong (2014:76) "place include company activities that make the product available to target consumers". Dengan kata lain tempat termasuk kegiatan perusahaan yang membuat produk tersedia untuk menargetkan konsumen.

Model penelitian

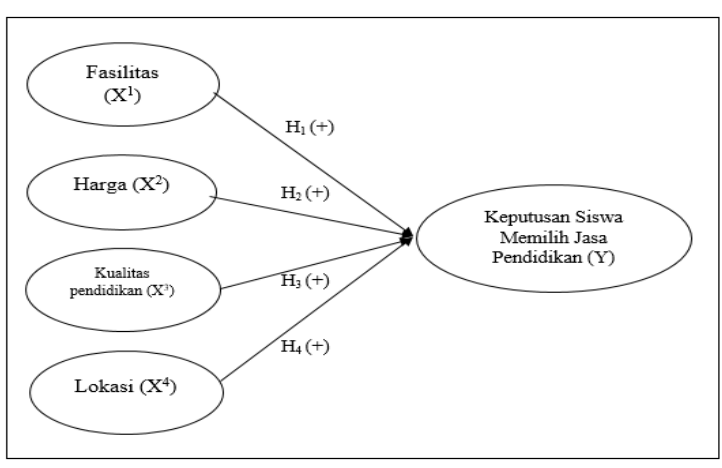

METODE

Metode penelitian secara umum diartikan sebagai cara ilmiah untuk mendapatkan data dengan tujuan dan kegunaan tertentu (Sugiyono 2018:1). Metode yang digunakan dalam penelitian ini adalah metode kuantitaf. Menurut Sugiyono (2018:15) metode kuantitatif adalah metode penelitian yang dilandaskan pada filsafat positivism, digunakan untuk meneliti pada populasi atau sampel tertentu, pengumpulan data menggunakan instrument penelitian, analisis data bersifat kuantitatif/statistic, dengan tujuan untuk menggambarkan dan menguji hipotesis yang telah di tetapkan. Dalam penelitian ini populasi yang akan digunakan adalah seluruh siswa SMK Muhammadiyah Imogiri jurusan Tata Busana sebanyak 113 orang. Sampel adalah bagian dari jumlah dan karakteristik yang dimiliki oleh populasi tersebut. Bila populasi besar, dan peneliti tidak mungkin mempelajari semua yang 
ada pada populasi, misalnya karena keterbatasan dana, tenaga dan waktu, maka peneliti dapat menggunakan sampel yang diambil dari populasi itu (Sugiyono 2019 : 62). Sampel dalam penelitian ini adalah sebagian dari siswa SMK Muhammadiyah Imogiri jurusan Tata Busana.

Metode pengumpulan data yang digunakan dalam penelitian ini adalah dengan metode kuesioner yaitu teknik pengumpulan data yang dilakukan dangan cara memberi seperangkat pertanyaan atau pertanyaan tertulis kepada responden untuk dijawabnya (Sugiyono 2018:219). Kuesioner dapat berupa pertanyaan/ penyataan tertutup atau terbuka, dapat diberikan kepada responden secara langsung atau dikirim melalui pos, atau internet. Alat ukur variabel skala pengukuran yang digunakan adalah skala likert dengan lima alternatife jawaban. Skala likert digunakan untuk mengukur sikap, pendapat, dan persepsi seseorang atau sekelompok orang tentang fenomena sosial dalam suatu penelitian (Sugiyono 2018:152).

\section{HASIL}

penelitian dan pengaruh empat variabel bebas (fasilitas, harga, kualitas pendidikan dan lokasi) dengan variable terikat (keputusan siswa memilih) jasa pendidikan Sekolah Menengah Kejuruan Muhammadiyah Imogiri. Setelah melakukan penelitian, maka diperoleh data tentang pengaruh fasilitas, harga, kualitas pendidikan dan lokasi terhadap keputusan siswa memilih jasa pendidikan SMK Muhammadiyah Imogiri dengan menggunakan kuisioner atau angket. Adapun jumlah pernyataan yang digunakan untuk penelitian sejumlah 18 item instrumen yang terdiri dari 4 item instrumen variabel fasilitas, 4 item instrument variabel harga, 4 item instrument variabel kualitas, 3 item instrument variabel lokasi, dan 3 item instrument variabel keputusan siswa yang disebar kepada seluruh siswa SMK Muhammadiyah Imogiri jurusan Tata Busana berdasarkan data yang tersedia sebanyak 113 siswa. Seiring berjalannya waktu ada beberapa siswa yang mengundurkan diri dengan berbagai macam alasan, diantaranya karena pindah sekolah, faktor ekonomi, faktor keluarga dan sebagainya, sehingga kuisioner atau angket tersebar kepada seluruh siswa SMK Muhammadiyah Imogiri jurusan Tata Busana yang masih aktif sebanyak 102 siswa.
Menurut Kotler dan Keller (2009:75) menyatakan bahwa fasilitas adalah segala sesuatu yang bersifat peralatan fisik dan disediakan oleh pihak penjual jasa untuk mendukung kenyamanan konsumen. Fasilitas belajar merupakan sarana dan prasarana pembelajaran. Prasarana meliputi gedung sekolah, ruang belajar, lapangan olahraga, ruang ibadah, ruang kesenian dan peralatan olah raga. Sarana pembelajaran meliputi buku pelajaran, buku bacaan, alat dan fasilitas laboraturium sekolah dan berbagai media pembelajaran yang lain.Hasil uji hipotesis menunjukkan bahwa diketahui nilai signifikan variabel fasilitas sebesar $0,299>0,05$. Nilai signifikan yang lebih besar dari 0,05 menunjukkan pada taraf kesalahan 5\%, maka dapat disimpulkan bahwa $\mathrm{H}_{1}$ ditolak. Artinya tidak ada pengaruh fasilitas $\left(X^{1}\right)$ terhadap keputusan siswa memilih jasa pendidikan (Y). Hasil penelitian menunjukkan bahwa variabel harga memiliki pengaruh positif terhadap keputusan siswa memilih jasa pendidikan. Hasil ini memberikan bukti empiris bahwa SPP yang terjangkau, Biaya pembangunan yang terjangkau oleh orangtua wali, biaya praktik yang terjangkau dan pengurusan administrasi yang mudah serta adanya beasiswa menjadi pertimbangan dalam menentukan keputusan siswa memilih jasa pendidikan.

Menurut Tjiptono menyebutkan bahwa harga merupakan satusatunya unsur bauran pemasaran yang mendatangkan pemasukan atau pendapatan bagi perusahaan. Sedangkan menurut Alma (2018:171) mengemukakan bahwa harga adalah nilai suatu barang yang dinyatakan dengan uang. Harga dalam konteks jasa pendidikan merupakan seluruh biaya yang dikeluarkan oleh siswa untuk mendapatkan jasa pendidikan yang ditawarkan oleh suatu jasa pendidikan.Penetapan harga ( SPP. Biaya pembangunan, biaya laboratoriun, biaya praktik jurusan) adalah elemen harga jasa pendidikan, pemberian beasiswa prosedur pembayaran dan syarat cicilan. Hasil uji hipotesis menunjukkan bahwa diketahui nilai signifikan variabel harga sebesar 0,094<0,1. Nilai signifikan yang lebih kecil dari 0,1 menunjukkan pada taraf kesalahan 10\%, maka dapat disimpulkan bahwa $\mathrm{H}_{2}$ diterima. Artinya ada pengaruh harga $\left(X^{2}\right)$ terhadap keputusan siswa memilih jasa pendidikan (Y). Hasil penelitian menunjukkan bahwa variabel harga memiliki pengaruh positif terhadap keputusan siswa 
memilih jasa pendidikan. Hasil ini memberikan bukti empiris bahwa SPP yang terjangkau, Biaya pembangunan yang terjangkau oleh orangtua wali, biaya praktik yang terjangkau dan pengurusan administrasi yang mudah serta adanya beasiswa menjadi pertimbangan dalam menentukan keputusan siswa memilih jasa pendidikan.

Menurut Kotler dan Keller (2016:164) kualitas produk adalah kemampuan suatu barang untuk memberikan hasil atau kinerja yang sesuai bahkan melebihi dari apa yang diinginkan pelanggan. Kualitas atau mutu pendidikan mengacu pada proses pendidikan dan hasil pendidikan, atau prestasi yang dicapai oleh sekolah pada setiap kurun waktu tertentu. Prestasi yang dicapai atau hasil pendidikan (student achievement) dapat berupa hasil test kemampuan akademis, dapat pula prestasi dibidang lain seperti di suatu cabang olah raga, seni atau keterampilan tambahan tertentu. Bahkan prestasi sekolah dapat berupa kondisi yang tidak dapat dipegang (intangible) seperti suasana disiplin, keakraban, saling menghormati, kebersihan dan sebagainya. Hasil uji hipotesis menunjukkan bahwa diketahui nilai signifikan variabel kualitas pendidikan sebesar $0,001<0,05$. Nilai signifikan yang lebih kecil dari 0,05 menunjukkan pada taraf kesalahan 5\% maka dapat disimpulkan bahwa $\mathrm{H}_{3}$ diterima. Artinya ada pengaruh kualitas $\left(X^{3}\right)$ terhadap keputusan siswa memilih jasa pendidikan $(\mathrm{Y})$.

\section{KESIMPULAN}

Penelitian tentang analisis determinan keputusan siswa memilih jasa pendidikan di SMK Muhammadiyah Imogiri (studi kasus pada jurusan Tata Busana) ini bertujuan untuk mengetahui seberapa besar pengaruh keputusan siswa memilih jasa pendidikan. Berdasarkan hasil analisis data dan kajian konsep, penelitian ini dapat disimpulkan sebagai berikut: Tidak ada pengaruh variabel fasilitas terhadap keputusan siswa memilih jasa pendidikan SMK Muhammadiyah Imogiri. Ada pengaruh variabel harga terhadap keputusan siswa memilih jasa pendidikan SMK Muhammadiyah Imogiri. Ada pengaruh variabel kualitas pendidikan terhadap keputusan siswa memilih jasa pendidikan SMK Muhammadiyah Imogiri. Tidak ada pengaruh variabel lokasi terhadap keputusan siswa memilih jasa pendidikan SMK Muhammadiyah Imogiri.

Sebagai pelengkap terhadap keputusan siswa memilih jasa pendidikan yang diberikan kepada SMK Muhammadiyah Imogiri, agar meningkatkan pelayanan fasilitas pendidikan baik fasilitas gedung maupun fasilitas pembelajaran, agar tetap terjangkau oleh seluruh kalangan tanpa kehilangan kualitasnya yang sudah baik. SMK Muhammadiyah Imogiri juga harus mempertahankan kemudahan dalam pelayanan pengurusan administrasi dan pemberian beasiswa bagi yang berprestasi maupun tidak mampu, kualitas pendidikan yang diperoleh peserta didik SMK Muhammadiyah Imogiri harus dipertahan dan ditingkatkan untuk menghadapi persaingan lulusan yang semakin ketat serta banyak dibutuhkan dalam DuDi (Dunia Usaha Dunia Industri). Lokasi SMK Muhammadiyah Imogiri yang strategis dan mudah dijangkau perlu adanya pengembangan penghiajauan atau pembuatan taman agar lebih asri dan nyaman. Penambahan tenaga kebersihan atau cleanning service untuk peningkatan kebersihan lingkungan sekolah agar tetap terjaga kebersihan dan kesehatan seluruh warga sekolah. 


\section{DAFTAR PUSTAKA}

1. Basu swastha Dharmmesta dan Hani Handoko. (2016). Manajemen Pemasaran: Analisa Perilaku Konsumen. Yogyakarta: BPFE.

2. Buchari Alma (2018). Manajemen Pemasaran dan Pemasaran Jasa. Bandung: Aftabeta.

3. Fandy Tjiptono. (2015). Strategi Pemasaran, edisi keempat. Edisi I. Yogyakarta: Andi.

4. Imam Ghozali. (2018). Aplikasi analisis Multivariate Dengan Program IBM SPSS 25. Semarang: Badan Penerbit Universitas Diponegoro.

5. Philip Kotler dan Garry Armstrong. (2016). Prinsip-Prinsip Pemasaran. Edisi 13. Jilid 1. Jakarta: Erlangga.
6. Philip Kotler dan Garry Armstrong.. (2014). Prinsip-Prinsip Pemasaran Jilid I. Jakarta: Erlangga.

7. Philip Kotler dan Kevin Lane Keller. (2009). Manajemen pemasaran Jilid 1. Jakarta: Erlangga

8. Philip Kotler dan Kevin Lane Keller. (2016). Marketing Management. Edisi 15. Jakarta: Erlangga.

9. Rambat Lupiyoadi. (2013). Manajemen Pemasaran Jasa: Berbasis Kompetensi Edisi 3. Jakarta: Salemba Empat.

10. Sugiyono. (2018). Metode Penelitian Kuantitatif. Bandung: Alfabeta.

11. Sugiyono. (2019). Statistik Untuk Penelitian. Bandung: Alfabeta. 